\title{
Kesantunan Berbahasa Mahasiswa Pada Pesan WhatsApp Kepada Dosen
}

\section{Sri Nur Yuliyawatia,1}

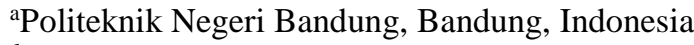

${ }^{1}$ srinuryuli@polban.ac.id

Article info

Article history:

Received: 13-09-2019

Revised : 30-01-2020

Accepted: 24-04-2020

Keywords: investigation, language politeness, student WhatsApp

\section{A B S T R A C T}

Communication between lecturers and students is generally conducted through WhatsApp (WA). Student messages addressed to lecturers through WA apparently sometimes use impolite language. For this reason, an investigation of language politeness student WA messages addressed to lecturers was conducted. The purpose of this study is to investigate and assess language politeness contained in WA messages addressed by students to lecturers. The research method used was a descriptive method in which WA messages from 71 Politeknik Negeri Bandung students with a total of 446 speeches were used as data. Referring to politeness etiquette for students who want to contact lecturers through mobile phones established by Universitas Indonesia (UI) and Universitas Gajah Mada (UGM), it is known that language politeness in Polban student WA messages addressed to lecturers ranges from $51 \%$ to $75 \%$ or it is considered polite. It means that their WA messages consist of 5 to 6 politeness criteria: time consideration (delivery time does not interfere with breaks or worship), greeting, apology, introduction by name and department/study program, polite language use, and gratitude (saying thank you). Thus, the student WA messages addressed to lecturers have met the politeness etiquette established by UI and UGM.

Komunikasi antara dosen dengan mahasiswa pada umumnya dilakukan melalui WA (WhatsApp). Penulisan pesan dari mahasiswa yang ditujukan kepada dosen melalui WA disinyalir kadang menggunakan bahasa yang tidak santun. Untuk itu, dilakukan "Investigasi Kesantunan Berbahasa Pesan Mahasiswa yang Ditujukan Kepada Dosen melalui Whatsapp". Tujuan penelitian ini untuk menginvestigasi dan menilai kesantunan yang terdapat pada pesan yang disampaikan mahasiswa kepada dosen melalui WA. Metode penelitian yang digunakan adalah metode deskriptif dengan menggunakan data penelitian yang terdiri atas WA dari 71 mahasiswa Politeknik Negeri Bandung dengan tuturan berjumlah 446. Dengan merujuk kepada kesantunan/tatakrama untuk mahasiswa yang ingin menghubungi dosen melalui telepon genggam atau handphone yang ditetapkan UI dan UGM diketahui secara umum nilai kesantunan bahasa WA mahasiswa berada di rentang 51\%-75\%. Artinya, pada pesan yang disampaikan mahasiswa kepada dosen melalui WA terdapat/tersurat 5 s.d. 6 kriteria kesantunan: pertimbangan waktu (waktu pengiriman tidak mengganggu istirahat atau ibadah), salam, permintaan maaf, pengungkapkan nama dan departemen/program studi, penggunaan bahasa yang sopan, dan ucapan terima kasih. Dengan demikian, pesan WA mahasiswa yang ditujukan kepada dosen telah memenuhi etika kesopanan seperti yang ditetapkan oleh UI dan UGM.

Copyright ( 2020 Institut Agama Islam Negeri Syekh Nurjati Cirebon. 


\section{PENDAHULUAN}

Perkembangan telepon genggam membuat masyarakat dapat berkomunikasi langsung dari jarak jauh dengan media sosial telepon, email, SMS, FB, instagram, telegram, dan WA (WhatsApp). Perkembangan teknologi telah memengaruhi banyak aspek dalam kehidupan manusia, tak terkecuali dalam kegiatan komunikasi. Aplikasi WA menjadi salah satu aplikasi yang paling banyak digunakan oleh berbagai macam kelompok masyarakat di Indonesia, tak terkecuali oleh para akademisi perguruan tinggi (Sukrillah, Ratnamulyani, Kusumadinata, 2017). Cara berkomunikasi antara mahasiswa dengan dosen telah berubah dengan adanya penggunaan telepon genggam. Saat ini sudah lumrah mahasiswa menghubungi dan berkomunikasi dengan dosen tentang segala hal dengan aplikasi WA yang terdapat di telepon genggam. Hal ini dikarenakan dapat secara langsung dan cepat. WA sudah menjadi andalan mahasiswa saat berkomunikasi dengan dosen. WA memberikan kesempatan bagi siapa pun termasuk sivitas akademika untuk menyelenggarakan berbagai kelas virtual berbasis online system dan fitur multimedia tanpa batasan ruang dan waktu (Jumiatmoko, 2016).

Walaupun menggunakan telepon genggam, berkomunikasi dengan dosen tetap memerlukan etiket agar komunikasi dapat berlangsung sesuai dengan harapan. Dalam komunikasi, hal yang sangat penting untuk diperhatikan adalah kesantunan berbahasa. Saat berkomunikasi, tatanan budaya harus diperhatikan, bukan sekadar mengemukakan gagasan (Muslich, 2009; Prawono, 2009). Unsur budaya yang berlaku dalam masyarakat harus menjadi acuan berbahasa. Penggunaan bahasa yang santun atau sopan, halus, baik, dan selalu hormat kepada teman berbicara akan tercermin dalam kesantunan berbahasa. Kesantunan berbahasa sangat berperan dalam kompetensi berbahasa setiap orang. Jika seseorang selalu berbahasa yang baik dan selalu menjaga kesantunan berbahasanya, orang tersebut akan berkepribadian sangat baik. Seseorang memiliki kepribadian kurang baik, satu di antaranya dapat disebabkan oleh selalu digunakannya bahasa tidak sopan dan kasar oleh orang tersebut.

Kesantunan atau yang biasa disebut tatakrama merupakan aturan perilaku yang ditetapkan dan disepakati bersama oleh suatu masyarakat atau disepakati oleh perilaku sosial (Muslich, 2009). Salah satunya adalah etiket berkomunikasi menggunakan telepon genggam. Pentingnya etiket tersebut membuat dua universitas ternama di Indonesia mengeluarkan petunjuk berkomunikasi dengan dosen menggunakan telepon genggam. Akmala (2018) menyatakan bahwa dua univeritas bergengsi di Indonesia, yaitu Universitas Indonesia (UI) dan Universitas Gadjah Mada (UGM) mengedukasi mahasiswanya mengenai etika mengirim pesan ke dosen yang dipajang di setiap gedung fakultas hingga terpampang di website resmi Universitas. Berikut ini foto banner yang berisi etika mengirim pesan ke dosen milik UGM, tepatnya milik Departemen Teknik Elektro dan Teknologi Informasi. 


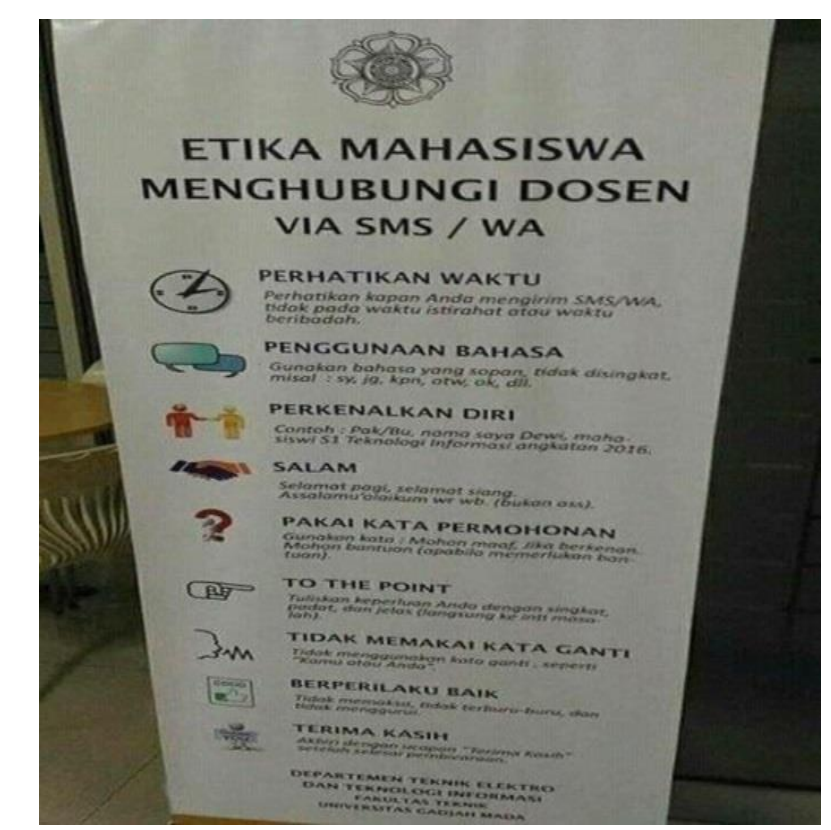

Gambar 1. Banner Etika Mahasiswa Menghubungi Dosen Sumber: https://www.brilio.net/2018

Terdapat tujuh etiket yang ditetapkan, yaitu: waktu, salam pembuka, permintaan maaf, identitas, bahasa, jelas, dan terima kasih (Fauzan, 2017; Ramdhani, 2017). Begitu pula, di kampus UGM (Universitas Gajah Mada), ditentukan sembilan etiket, yaitu: waktu, bahasa, perkenalkan diri, salam, kata permohonan, keperluan, tidak memakai kata ganti, berperilaku baik, terima kasih (Akmala, 2018). Pada dasarnya, keduanya adalah sama.

Dikutip dari Mutiara (2018), Kepala Bidang Humas dan Protokol UGM Iva Ariani membenarkan banner tersebut dipasang di Fakultas Teknik. Iva mengatakan banner itu dipasang bukan karena ada masalah dengan sopan santun mahasiswa. Banner itu hanya untuk mengingatkan kembali. Penelitian Suntoro (2018) menyatakan bahwa komunikasi melalui WA menyebabkan terjadinya banyak pelanggaran kesantunan berbahasa, termasuk juga dalam dunia akademik. Pelanggaran-pelanggaran tersebut lebih pada prinsip kesantunan ketika komunikasi berbasis WA (Suntoro, 2019). Kekurangsantunan penggunaan bahasa saat berkomunikasi menggunakan media sosial terjadi pula di Malaysia. Sur-el dan SMS dari mahasiswa kepada dosen di universitas swasta di Malaysia, dimulai dengan menuliskan salam informal yang menunjukkan ketidaksopanan (Faiz \& Lin, 2014). Kekurangsantunan tersebut pun terjadi dalam komunikasi mahasiswa pascasarjana dengan dosennya di Libya (Alsout \& Khedri, 2019).

Pada umumnya, komunikasi antara dosen dan mahasiswa Polban (Politeknik Negeri Bandung) dilakukan dengan menggunakan WA. Penggunaan WA dianggap lebih murah, cepat, efisien, dan lebih mudah dibuka. Pesan WA lebih mudah dibaca kapan pun dan di mana pun. Penulisan pesan dari mahasiswa yang ditujukan kepada dosen melalui WA disinyalir kadang menggunakan bahasa yang tidak santun; bahasa pergaulan yang popular di kalangan remaja. Bahkan pesan tersebut menggunakan kata kurang sopan. Kecepatan, kemudahan, dan kepraktisan berkomunikasi dengan gawai inilah sehingga kesantunan ketika berkomuniukasi dengan dosen kadang dilupakan oleh mahasiswa. Padahal berkomunikasi dengan menggunakan media apa pun, kesantunan berbahasa tetap 
harus diterapkan. Berdasarkan hal tersebut, tujuan penelitian ini adalah menginvestigasi dan menilai kesantunan bahasa pesan yang disampaikan mahasiswa Polban kepada dosen melalui WA.

Penelitian mengenai berbagai aspek tentang WA telah banyak dilakukan. Suryadi, Ginanjar, \& Priyatna (2018) dan Sartikasari (2018) WA yang dikaitkan dengan pembelajaran. Nurdiarti (2018) meneliti WA yang dihubungkan dengan pola interaksi dan relasi sosial. Sahril (2016) meneliti WA yang dihubungkan dengan pemertahanan bahasa ibu. Penelitian WA yang dikaitkan dengan bahasa telah pula dilakukan Pratamanti, dkk. (2017) dan disimpulkan bahwa penggunaan bahasa gaul (aku, kok, nggak), pembahasan di luar konteks perkuliahan, cara pengungkapan maksud yang tidak sopan, dan penggunaan aspek paralinguistik yang tidak tepat. Sutarma (2016) dan Oktavia (2018) menemukan wujud-wujud linguistik dalam WA. Nur, dkk. (2017) menemukan tindak tutur pada WA.

Penelitian ini berbeda dengan penelitian-penelitian tersebut karena berfokus pada kesantunan berbahasa mahasiswa Politeknik Negeri Bandung. Dengan demikian, pada penelitian ini akan diperoleh pola kesantuanan berbahasa mahasiswa Politeknik Negeri Bandung.

\section{METODE}

Sesuai dengan permasalahan, dalam penelitian ini akan digunakan metode deskriptif. Penggunaan metode deskriptif penulis pandang relevan dengan alasan karena penelitian ini bertujuan memberikan deskripsi mengenai hasil pengkajian pada masalah yang diteliti. Populasi penelitian ini adalah pesan melalui WA yang disampaikan mahasiswa kepada dosen Polban. Penentuan pesan melalui WA yang dijadikan sampel akan dilakukan dengan cara sampel purposif yaitu sampel yang ditentukan dengan sengaja karena alasan-alasan diketahuinya sifat-sifat sampel tersebut.

Sumber data penelitian ini adalah WA yang ditulis oleh 39 mahasiswa rekayasa dan 32 mahasiswa nonrekayasa Polban. WA tersebut dikirimkan kepada 5 dosen, yaitu dosen mata kuliah Fisika, Matematika, Bahasa Indonesia, dan Bahasa Inggris. Data dalam penelitian ini adalah 449 percakapan tertulis mahasiswa kepada dosen melalui media sosial WA. Untuk mendapatkan data yang relevan dengan permasalahan dan tujuan penelitian digunakan teknik pengumpulan data berupa analisis/telaah Pustaka.

Instrumen pertama penelitian ini adalah untuk mengukur kesantunan bahasa pesan kepada dosen melalui WA tiap-tiap mahasiswa atau masing-masing data. Kesantunan bahasa setiap pesan mahasiswa kepada dosen melalui WA dinilai dengan menggunakan intrumen kategori kesantunan yang dibuat dengan berdasarkan petunjuk etiket kesantunan dibuat UI dan UGM. Digunakannya kriteria kesantunan yang ditetapkan UI dan UGM untuk menganalisis kesantunan berbahasa WA karena dianggap kriteria tersebut sangat teknis sehingga kesantunan bahasa WA dapat diukur. Berikut ini instrumen kategori kesantunan yang dibuat berdasarkan petunjuk etiket kesantunan dibuat UI dan UGM. 
Tabel 1. Kategori Kesantuan Bahasa WA

\begin{tabular}{ll}
\hline \multicolumn{1}{c}{ Kriteria } & \multicolumn{1}{c}{ Indikator } \\
\hline sangat santun & $\begin{array}{l}\text { Pada pesan yang disampaikan mahasiswa kepada dosen melalui } \\
\text { WhatsApp tersurat tujuh kriteria kesantunan, yaitu waktu, salam, } \\
\\
\text { ungkapan maaf, identitas, bahasa baku, pesan jelas, dan ucapan } \\
\text { terima kasih. }\end{array}$ \\
& Pada pesan yang disampaikan mahasiswa kepada dosen melalui \\
santun & WhatsApp terdapat/tersurat 5 s.d. 6 kriteria kesantunan. \\
\multirow{2}{*}{ kurang santun } & Pada pesan yang disampaikan mahasiswa kepada dosen melalui \\
& WhatsApp terdapat/tersurat 3 s.d. 4 kriteria kesantunan. \\
tidak santun & Pada pesan yang disampaikan mahasiswa kepada dosen melalui \\
& WhatsApp terdapat/tersurat 1 s.d. 2 kriteria kesantunan. \\
\hline
\end{tabular}

Instrumen kedua penelitian ini untuk mengukur secara general kesantunan bahasa mahasiswa Polban pada pesan yang disampaikan kepada dosen melalui WA Setelah tiap-tiap pesan mahasiswa dikategorikan kesantunan bahasanya, dilanjutkan dengan penilaian secara general kesantunan bahasa pesan yang disampaikan mahasiswa kepada dosen melalui WA dengan skala interval sebagai berikut.

1. Bahasa WA mahasiswa Polban akan dinilai sangat santun apabila $76 \%-100 \%$ dari jumlah data memiliki ketujuh kriteria kesantuan pada pesan yang disampaikan mahasiswa kepada dosen melalui WA.

2. Bahasa WA mahasiswa Polban akan dinilai santun apabila 51\%-75\% dari jumlah data memeliki lima sampai enam kriteria kesantuan pada pesan yang disampaikan mahasiswa kepada dosen melalui WA.

3. Bahasa WA mahasiswa Polban akan dinilai kurang santun apabila $26 \%-50 \%$ dari jumlah data memeliki tiga sampai empat kriteria kesantuan pada pesan yang disampaikan mahasiswa kepada dosen melalui WA.

4. Bahasa WA mahasiswa Polban akan dinilai tidak santun apabila 1\%-25\% dari jumlah data memeliki satu sampai dua kriteria kesantuan pada pesan yang disampaikan mahasiswa kepada dosen melalui WA.

\section{Alur Penelitian}

Penelitian ini akan diawali dengan analisis pustaka berupa jurnal dan jenis publikasi lainnya untuk memperoleh informasi selengkap dan seakurat mungkin terkait bahasa pada WA dan kesantunan berbahasa. Langkah berikutnya dengan merujuk kepada etiket penggunaan telepon genggam yang ditetapkan UI dan UGM dibuat instrumen. Instrumen ini berupa pertanyaan sebagai pedoman untuk menginvestigasi dan menilai kesantunan pesan mahasiswa kepada dosen melalui WA. Penelitian ini akan diakhiri dengan pembuatan laporan. Alur penelitian ini dapat disimak pada gambar berikut ini. 


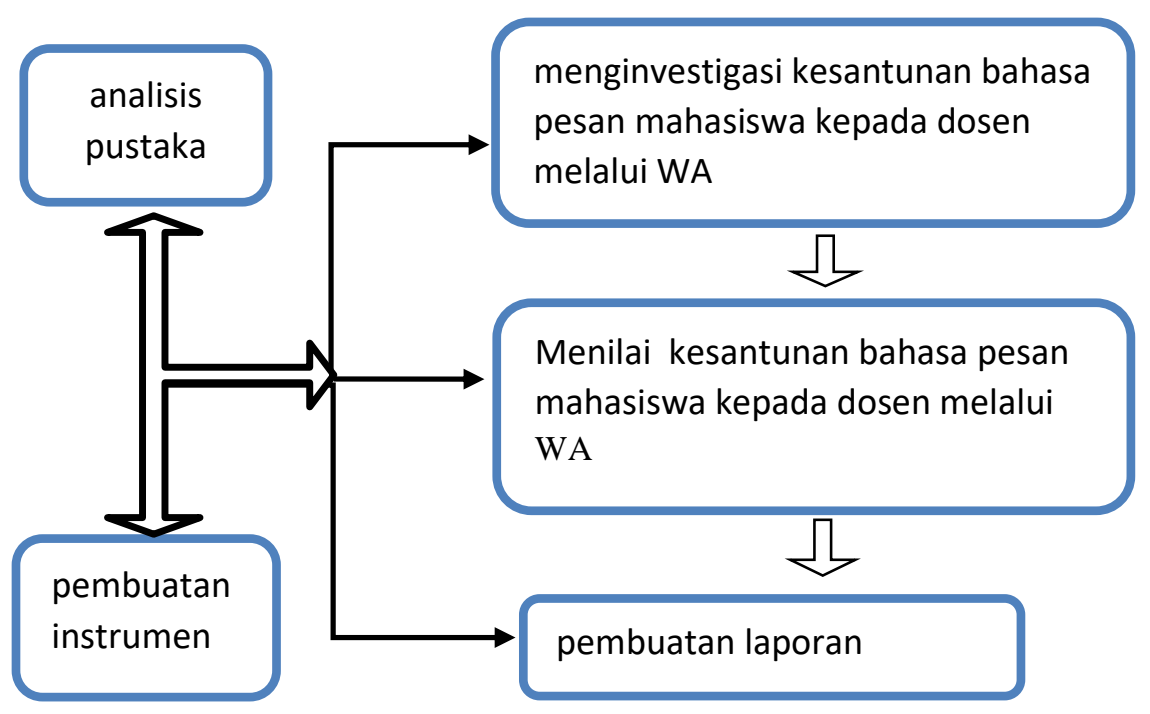

Gambar 2. Alur Penelitian

\section{HASIL DAN PEMBAHASAN}

Dari investigasi data berdasarkan penilaian kategori kesantunan diperoleh hasil seperti yang tertulis pada tabel 2 berikut ini.

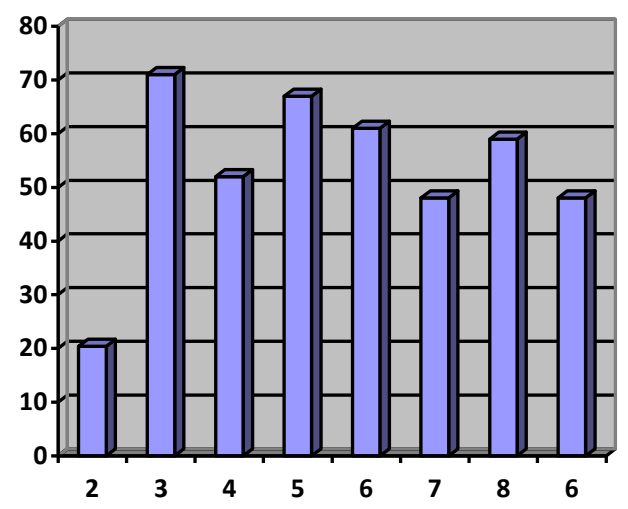

\section{Gambar 3. Penilaian Kesantunan Berbahasa}

Dari gambar 3 tersebut diketahui bahwa 64 WA dikirimkan pada waktu yang tepat, yaitu waktu perkuliahan/pagi dan siang dan 7 WA dikirim pada waktu yang kurang tepat yaitu malam hari. Dengan demikian, waktu pengiriman WA sebagian besar telah memenuhi kesantunan. 71 WA diawali dengan ucapan salam: selamat pagi/selamat siang/selamat malam atau assalamualaikum warahmataulahi wabarakatuh. Artinya, seluruh WA dibuka dengan kesantunan. Selain ucapan salam, terdapat 52 yang disertai permohonan maaf karena telah mengirim WA dan 19 WA tanpa menuliskan permohonan maaf. 67 WA menuliskan identitas dan WA tidak menuliskannya. Dengan demikian, pernyataan awal pada WA sebagian besar telah memenuhi kesantunan Penggunaan bahasa yang baku terdapat pada 61 WA dan 10 WA mengunakan bahasa pergaulan remaja. Terdapat 48 WA bertulisan pesan yang jelas dan 23 WA bertulisan pesan kurang jelas. Artinya, penggunaan bahasa pada WA sebagian besar sudah santun. Ucapan terima kasih 
untuk mengakhiri komunikasi terdapat pada 59 WA dan 12 WA tidak menuliskan ucapan terima kasih. Artinya sebagian besar WA diakhiri dengan santun.

Dengan merujuk kepada pada tabel 2 yaitu "Instrumen Kategori Kesantuan Bahasa WA", dari tabel 2 tersebut diketahui bahwa 17 WA termasuk kategori sangat santun, 49 WA termasuk kategori santun, 5 WA termasuk kategori kurang santun, dan tidak ada WA yang masuk kategori tidak santun. Berikut ini contohcontoh WA pada masing-masing kategori.

Contoh WA yang sangat santun, artinya pada WA tersebut tertulis 6 s.d. 7 etiket kasantunan.

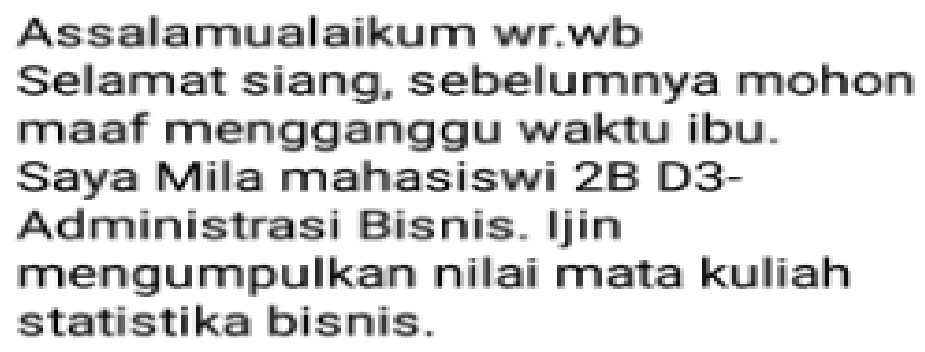

Terimakasih bu..

\section{Waalaikum salam wr.wb}

Gambar 4. Contoh WA dari Mahasiswa 1

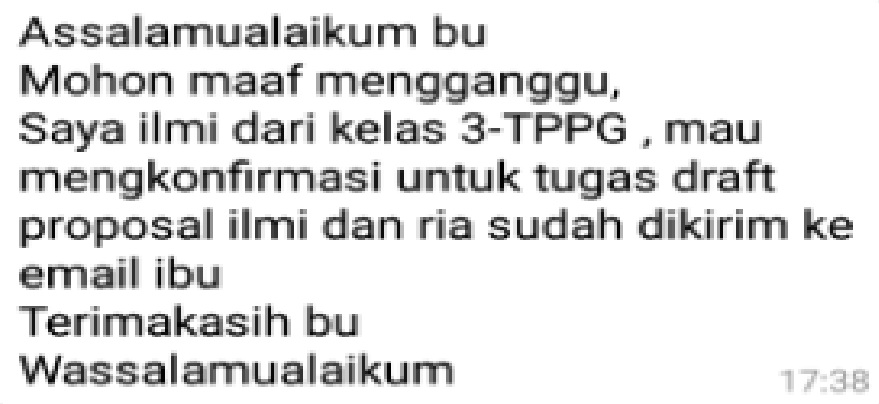

\section{Gambar 5. Contoh WA dari Mahasiswa 2}

Contoh WA yang santun, artinya pada WA tersebut tertulis 5-6 etiket kasantunan. Pada kedua WA berikut ini tidak terdapat salam penutup.

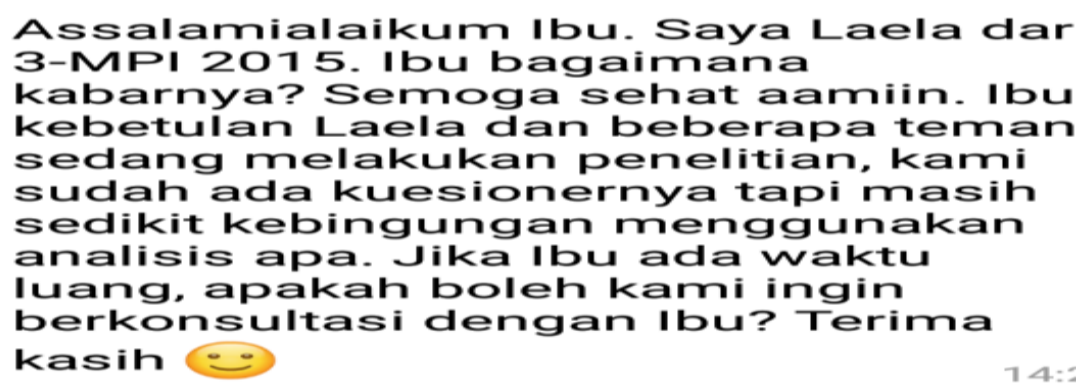

Gambar 6. Contoh WA dari Mahasiswa 3 


\section{Assalamualaikum bu maaf saya ganggu waktu istirahatnya. saya Renaldy Saleh dari kelas 1-TPJJ. saya ingin konfirmasi kalau saya sudah mengirim email mengenai tugas daftar pustaka. sebelumnya terimakasih bu}

Gambar 7. Contoh WA dari Mahasiswa 4

Contoh WA yang kurang santun, artinya pada WA tersebut tertulis 3-4 etiket kasantunan.

Kekurangsantunan pada WA berikut ini terdapat salam, identitas diri, pesan. Namun tidak terdapat permintaan maaf, ucapan terima kasih, salam, dan menggunakan bahasa nonformal.

\section{A Forwarded \\ Assalamualaikum wr wb, selamat siang bu, perkenalkan nama saya galang dwi mahasiswa d4 refri yang tugas akhir diuji sama ibu. Apakah hari ini bisa ketemu bu

Gambar 8. Contoh WA dari Mahasiswa 5

Pada ketiga WA berikut ini kekurangsantunan disebabkan tidak dituliskannya identitas diri, pesan berisifat memaksa untuk bertemu, dan tidak dituliskan salam penutup.

Assalamualaikum Bu 07:22

Mohon maaf Bu. barangkali hr ini ada waktu, saya ijin menghadap $07: 23$

Terimakasih $07: 23$

Gambar 9. Contoh WA dari Mahasiswa 6

\section{Assalamualaikum bu, izin bertanya, apakah ibu sudah dikampus?

Gambar 10. Contoh WA dari Mahasiswa 7 


\section{Assalamualaikum Bu. Selamat sore, Bu ingin bertanya apakah boleh revisi via email Bu? \\ Untuk tugas proposal Bu 18:50 \\ Oiya baik Bu. Mohon maaf bila mengganggu \\ Ohiya Bu ingin bertanya, untuk materinya apakah boleh kami minta (materi yg pernah Ibu jelaskan dikelas)?

Gambar 11. Contoh WA dari Mahasiswa 8

Dengan diketahuinya 17 WA termasuk kategori sangat santun, 49 WA termasuk kategori santun, 5 WA termasuk kategori kurang santun, maka diperoleh presentase kategori kesantunan sebagai berikut.

\section{Tabel 2. Presentase Kategori Kesantunan Berbahasa WhatsApp}

$\begin{array}{lll}\text { kategori } & \text { Jumlah data } & \text { presentase } \\ \text { Sangat santun } & 17 & 23,94 \% \\ \text { Santun } & 49 & 69,01 \% \\ \text { Kurang santun } & 5 & 7,04 \% \\ \text { Tidak santun } & 0 & 0\end{array}$

Dengan merujuk kepada skala interval pada instrumen kedua yang tertulis di metode, kesantunan bahasa pesan yang disampaikan mahasiswa Politeknik Negeri Bandung kepada dosen melalui WA secara general, pada umumnya berada di rentang 51\%-75\% atau dinilai santun. Artinya, pada pesan yang disampaikan mahasiswa kepada dosen melalui WA terdapat/tersurat 5 s.d. 6 kriteria kesantunan, yaitu waktu pengiriman yang tidak mengganggu istirahat atau beribadah, WA diawali dengan salam, mahasiswa menyampaikan permintaan maaf, memberitahukan identitas, pesan menggunakan bahasa yang sopan, dan disampaikan ucapan terima kasih. Dengan demikian, secara general nilai kesantunan bahasa pesan yang disampaikan mahasiswa Politeknik Negeri Bandung kepada dosen melalui WA adalah santun.

\section{SIMPULAN}

Hasil investigasi etiket kesantunan terhadap 446 percakapan tertulis dari 71 mahasiswa kepada 5 dosen melalui media sosial WA, diketahui bahwa 17 sangat santun, 53 WA santun, dan 5 WA kurang santun, tidak ditemukanWA yang tidak santun. Berdasarkan skala interval kesantunan berbahasa, secara general kesantunan berbahasa WA mahasiswa Politeknik Negeri Bandung 69,01\% berada di rentang 51\%-75\%. Artinya, pada pesan yang disampaikan mahasiswa kepada dosen melalui WA terdapat/tersurat 5 s.d. 6 kriteria kesantunan, yaitu waktu 
pengiriman yang tidak mengganggu istirahat atau beribadah, WA diawali dengan salam, mahasiswa menyampaikan permintaan maaf, memberitahukan identitas, pesan menggunakan bahasa yang sopan, dan disampaikan ucapan terima kasih. Dengan demikian, secara general nilai kesantunan yang terdapat pada pesan yang disampaikan mahasiswa kepada dosen melalui WA adalah santun sehingga dapat disimpulkan pesan mahasiswa Politeknik Negeri Bandung yang ditujukan kepada dosen melalui WA telah memenuhi atau sesuai dengan etiket kesantunan yang ditetapkan UI dan UGM.

\section{UCAPAN TERIMA KASIH}

Terima kasih disampaikan kepada UPPM Politeknik Negeri Bandung yang telah mendanai penelitian mandiri ini dengan Surat Perjanjian Pelaksanaan Penelitian Mandiri Nomor 438.16/PL1.R7/LT/2019.

\section{DAFTAR PUSTAKA}

Alsout, E., \& Khedri, M. (2019). Politeness in Libyan Postgraduate Students' eMail Requests Towards Lecturers. Journal of Language Communication, 6(1), 69-86.

Akmala, N. (2018). Cara Komunikasi Buruk Bisa Berakibat Fatal diakses pada 23 September 2019 di https://www.brilio.net.

Faiz, H., \& Lin, O. M. (2014). Use of Greetings in Messages from Students to Lecturers at a Hospitality College. BERJAYA Journal of Services \& Management, 2, 95-101.

Fauzan, A. (2017). Begini Etika Menghubungi Dosen lewat Handphone di UI! diakses pada 20 September 2019 di http://kabarkampus.com.

Jumiatmoko. (2016). Whatsapp Messenger dalam Tinjauan Manfaat dan Adab. Jurnal Wahana Akademika, 3(1), 51 - 66.

Muslich, M. (2009). Sebuah Kajian Sosiolinguistik. Jakarta: Bumi Aksara.

Mutiara, I. (2018). Viral Etika Mahasiswa Kontak Dosen di UGM: Dilarang Singkat 'Ass' diakses pada 21 September 2019 di https://news.detik.com/.

Nur, M. S., dkk. (2017). Kesantunan Berbahasa dalam Whatsapp (WA) Mahasiswa Terhadap Dosen Program Studi Pendidikan Bahasa dan Sastra Indonesia STKIP PGRI Sumatera Barat. Dinamika Sosial Budaya, 19(2), $230-239$.

Nurdiarti, R. P. (2018) Media Sosial, Pola Interaksi dan Relasi Sosial Pada Grup Whatsapp Alumni SDK. St. Maria Blitar. Jurnal ETTISAL, 3(1), 49 - 61.

Oktavia, W. (2018). Variasi Jargon Chatting Whatsapp Grup Mahasiswa Tadris Bahasa Indonesia. Jurnal KATA, 2(2), 317 - 325.

Pratamanti, E. D., dkk. (2017). Kesantunan Berbahasa dalam Pesan Whatsapp Mahasiswa yang Ditujukan Kepada Dosen. Dinamika Sosial Budaya, 19(2), $230-239$.

Prawono. (2009). Berbahasa Secara Santun. Yogyakarta: Pustaka pelajar.

Ramdhani, J. (2017). Dear Mahasiswa Jaman Now, UI Bikin Etika Kontak Dosen via WA diakses pada 25 September 2019 di Detik News https://news.detik.com/berita/.

Sahril. (2016). Pemertahanan Bahasa Ibu Melalui Grup WA. Jurnal Ranah, 5(1), $44-52$. 


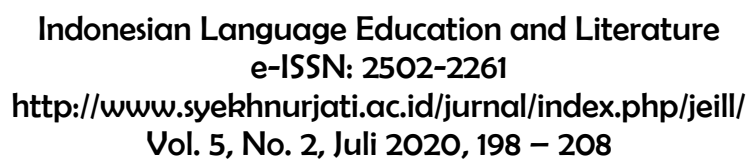

Sartikasari. (2018). Kegunaan Whatsapp Sebagai Media Informasi dan Media Pembelajaran Pada Mahasiswa Ilmu Komunikasi STISIP Persada Bunda. Jurnal Medium, 6(2), 15 - 26.

Sukrillah, A., Ratnamulyani, I.A., \& Kusumadinata, A.A. (2017). Pemanfaatan Media Sosial Melalui Whatsapp Group FEI Sebagai Sarana Komunikasi. Jurnal Komunikatio, 3(2), 95 - 103.

Suntoro. (2018). Pelanggaran Kesantunan Berbahasa Mahasiswa Pada Dosen Dalam Wacana Komunikasi Whatsapp di STAB Negeri Sriwijaya Tangerang. Jurnal Vijjacariya, 5(2), 79 - 92.

Suntoro. (2019). Kesantunan Berbahasa Mahasiswa Pada Dosen dalam Wacana Komunikasi Whatsapp di STABN Sriwijaya. Jurnal Pendidikan Bahasa dan Sastra Indonesia, 4(1), 39 - 46.

Sutarma, I. G. P. (2016). Analisis Wujud Bentuk Linguistik dalam Penggunaan Bahasa Indonesia di Media Sosial WhatsApp. Jurnal Sosial dan Humaniora, 6(3), 227 - 237.

Suryadi, M., Ginanjar, H., \& Priyatna, M. (2018). Penggunaan Sosial Media Whatsapp dan Pengaruhnya Terhadap Disiplin Belajar Peserta Didik Pada Mata Pelajaran Pendidikan Agama Islam (Studi kasus di SMK analis Kimia YKPI Bogor). Jurnal Pendidikan Islam, 07(1), 1 - 22. 